\title{
IMPLEMENTASI PROGRAM HOMESCHOOLING UNTUK ANAK USIA DINI DI SABUMI-Homeschooling Muslim Nusantara BANDUNG
}

\author{
Aghnia Dalila \\ Program Studi Pendidikan Guru Pendidikan Anak Usia Dini, Departemen Pedagogik, \\ Fakultas Ilmu Pendidikan, Universitas Pendidikan Indonesia \\ dalilaghnial@gmail.com \\ Euis Kurniati ${ }^{1}$ dan I Gusti Komang A. $\mathrm{A}^{2}$
}

\begin{abstract}
Homeschooling has now become an option for the parent to educate the child. The cause is because of the negative news that accessed regarding formal education, this reduces the confidence of parents towards formal education. There are advantages and disadvantages of homeschooling. The community is one of the solutions to overcome these weaknesses, but the issue appears because the lack of homeschooling adversely seeks information about homeschooling program set up by the community. This research aims to know the program implementation homeschooling for early childhood in SABUMIHomeschooling the Muslim archipelago (HSMN), Bandung. The methods used in this study using case studies. The technique of data collection is done with the interview, observation, and study of documentation. The results showed that homeschooling programs for early childhood in SABUMI-HSMN Bandung can overcome the negative issues of homeschooling program design for children, consisting of planning, implementation, and evaluation. Homeschooling program implementation for early childhood in Bandung HSMN SABUMI-using social media i.e. WhatsApp for programs online and offline programs as a complement in order to become a unified whole. There is a skew of internal barriers that desperately needs a commitment from members in implementing a program of homeschooling. Recommendations for managers SABUMI-HSMN Bandung make SOP's performance and evaluation of each program online offline, open registration and regulation provided provisions applicable to registered members became caretaker SABUMI - HSMN Bandung. For subsequent researchers to expand the scope of the subject of the family.
\end{abstract}

Keywords: homeschooling, early childhood education, programs.

\section{Abstrak : Implementasi Program Homeschooling Untuk Anak Usia Dini di SABUMI - Homeschooling Muslim Nusantara (HSMN) Bandung. Homeschooling kini menjadi pilihan bagi orang tua untuk mendidik anak. Penyebabnya karena berita negatif yang diakses mengenai pendidikan formal, hal ini mengurangi kepercayaan orang tua terhadap pendidikan formal. Homeschooling terdapat keunggulan dan kelemahan. Komunitas adalah salah satu solusi mengatasi kelemahan tersebut, namun isu negatif homeschooling muncul dikarenakan kurangnya mencari informasi mengenai program homeschooling yang dibentuk oleh komunitas. Penelitian ini bertujuan untuk mengetahui implementasi program homeschooling untuk anak usia dini di SABUMI-Homeschooling Muslim Nusantara (HSMN)}


Bandung. Metode yang digunakan dalam penelitian ini menggunakan studi kasus. Teknik pengumpulan data dilakukan dengan dengan wawancara, observasi dan studi dokumentasi. Hasil penelitian menunjukkan bahwa program homeschooling untuk anak usia dini di SABUMI-HSMN Bandung dapat mengatasi isu negatif homeschooling dengan rancangan program homeschooling untuk anak yang terdiri dari perencanaan, pelaksanaan dan evaluasi. Implementasi program homeschooling untuk anak usia dini di SABUMI-HSMN Bandung menggunakan media sosial yaitu whatsApp untuk program online dan program offline sebagai pelengkap agar menjadi kesatuan yang utuh. Kendala condong terdapat dari internal yang sangat membutuhkan komitmen dari anggota dalam mengimplementasikan program homeschooling. Rekomendasi bagi pengelola SABUMI-HSMN Bandung membuat SOP kinerja dan evaluasi setiap program online-offline,membuka pendaftaran serta peraturan dengan syarat ketentuan yang berlaku untuk anggota terdaftar menjadi pengurus SABUMI-HSMN Bandung. Bagi peneliti selanjutnya untuk memperluas subjek penelitian dengan lingkup keluarga.

Kata kunci : homeschooling, pendidikan anak usia dini, program.

\section{PENDAHULUAN}

Keluarga adalah unit terkecil dalam kehidupan sosial, dikarenakan orang yang terdapat di rumah ialah ayah, ibu dan anak. Keluarga memiliki tanggung jawab utama dan pertama terhadap pendidikan anak. Sesuai dengan hadist bahwa orangtua berkewajiban untuk memelihara dan mengurus anak-anaknya. Sistem pendidikan anak usia dini dipilih karena sebagai kebutuhan, yang disesuaikan oleh setiap keluarga.

Layanan Pendidikan Anak Usia

Dini terdiri dari jalur pendidikan informal berbentuk pendidikan keluarga, jalur pendidikan formal berbentuk TK, RA atau sederajat dan jalur pendidikan nonformal berbentuk homeschooling atau sekolah rumah yang berupa komunitas (Sujiono, 2009). Pendidikan anak usia dini tumbuh dengan pesat di masyarakat. Dengan perkembangan informasi dan teknologi membuat masyarakat sadar dengan pendidikan anak usia dini. Orang tua menjadi selektif dalam memilih pendidikan untuk anak dari berbagai informasi diperoleh.

Permasalahan yang dalam pendidikan formal muncul seperti cara belajar yang tidak sesuai dengan cara belajar anak, program calistung yang tidak menyenangkan. Hal yang memperburuk dari pendidikan formal ialah kasus bullying, kasus pelecahan seksual, kasus, pemasungan kreativitas anak (Adilistiono, 2010). Dikutip dari beberapa berita, seperti mengenai kasus pelecahan seksual di TK di daerah Pondok Indah Jakarta Selatan (Liputan6.com, terbitan 14 April 2014), pornografi (Liputan6.com, terbitan 15 Juni 2014). Hal ini sesuai dengan pendapat Hanaco (2012) pendidikan formal membuat manusia menjadi makhluk yang pasif, sedangkan pada dasarnya manusia adalah makhluk yang suka belajar.

Penelitian Raymond dan Dorothy Moore mengenai efek dari pendidikan anak usia dini (dalam Hanaco, 2012) menemukan bahwa kecenderungan 
orang tua menyekolahkan anak sejak awal tidaklah efektif dan cenderung member efek kurang baik pada anak. Sebaliknya, anak-anak yang dididik sendiri oleh ibunya memiliki kecenderungan lebih pintar dibandingkan anak yang menjalani sekolah formal. Bahkan pendidikan formal yang mengajukan anak-anak untuk diterima di SD dengan syarat memiliki kemampuan membaca yang baik. Hal ini yang membuat ambisi orang tua menjadi tinggi kepada anak untuk dapat membaca. Agar dapat memasukkan anak ke pendidikan selanjutnya.

Penyebab inilah orang tua memilih homeschooling sebagai alternatif pendidikan karena meningkatnya pengetahuan dan berkembanganya informasi yang mengalami berbagai perubahan dengan perkembangan zaman serta cara pandang. Alasan orang tua memilih homeschooling ialah (1) pendidikan sesuai, keinginan, (2) fleksibilitas, (3) belajar dari rasa ingin tahu, (4) mandiri, (5) kesempatan mengenali potensi (Hanaco, 2012).

Keunggulan dari sekolah di rumah (homeschooling) ialah orang tua mengetahui perkembangan anak dengan mengarahkan kepada hal yang diminati oleh anak, sehingga anak menjadi ahlinya. Selain itu, kemampuan berfikir yang baik, terdiri dari kemampuan kreatif, kemampuan eksplorasi, kemampuan menambil keputusan, memiliki akhlak yang baik dengan kemampuan entrepreneurship, artinya ia mampu menjual ide yang ia produksi, serta membuat suasana belajar yang menyenangkan (Griffith, 2008).

\begin{tabular}{llr}
\multicolumn{1}{c}{ Akan } & tetapi, homeschooling \\
memiliki & kelemahan & seperti \\
membutuhkan & disiplin dan & komitmen
\end{tabular}

yang tinggi, sulit mengukur kemampuan anak, tanggung jawab tergolong kompleks pada orangtua, kurangnya kemampuan untuk bekerja dalam tim, anak kurang berinterkasi dengan teman sebaya, kesulitan mengikuti ujian persamaan, sulitnya anak menghadapi situasi sosial yang kompleks (Hanoco, 2012).

Hal inilah menjadi tugas utama orang tua mencari informasi untuk mengatasi kelemahan pada pendidikan homeschooling. Seperti halnya pendapat dari Dobson (2005) kelemahan dari homeschooling diatasi dengan cara membaca buku mengenai sekolah rumah, mencari kelompok pendukung dan temui keluarga yang memilih homeschooling (komunitas), menghadiri pertemuan atau talkshow mengenai homeschooling, menjadi bagian dari komunitas homeschooling yang terakhir mengamati kemajuan anak.

Orang tua mengikuti komunitas untuk memperluas wawasan dengan mencari inspirasi melalui diskusi-diskusi oleh praktisi homeschooling dan memilih yang sesuai dengan visi, misi, tujuan dalam keluarga. Di era modern ini dengan mudah mencari komunitas homeschooling, tetapi terdapat kesulitan dikarenakan dalam proses program yang diberikan tidak sesuai dengan visi, misi dan tujuan dalam keluarga. Kebanyakan komunitas homeschooling menawarkan pertemuan yang tidak formal untuk bertemu dan menghabiskan waktu dengan keluarga lainnya dengan berbagai acara dan kegiatan (Kho, 2007).

Komunitas menjadi salah satu solusi dalam mengatasi kelemahan mengenai homeschooling sebagai pilihan pendidikan bagi anak. Namun demikian, ditemukan isu dari homeschooling seperti pendapat Dobson (2005, hlm. 91) 
kurang sosialisasi anak terhadap lingkungan, keraguan orang tua memberikan pendidikan untuk anak. Homeschooling hanya untuk keluarga kaya, homeschooling gagap teknologi, harus adanya alokasi waktu belajar seperti sekolah, peserta homeschooling tidak disiplin (Kembara, 2007, hlm. 76).

Isu tersebut hadir dikarenakan kelemahan dari homeschooling. Isu homeschooling dapat diatasi dengan mendapatkan solusi dari keluarga homeschooling atau komunitas homeschooling. Salah satu komunitas homeschooling di Bandung yang mengimplementasikan program homeschooling untuk anak tersebut adalah SABUMI - Homeschooling Muslim Nusantara (HSMN) Bandung.

Terkait paparan diatas, penulis tertarik untuk meneliti program homeschooling untuk anak usia dini di SABUMI - Homeschooling Muslim Nusantara (HSMN) Bandung dengan mengatasi mengenai isu homeschooling. Pengalaman SABUMI-HSMN Bandung mengimplementasikan program homeschooling untuk anak usia dini diharapkan bisa menjadi sumber informasi dan pengetahuan mengenai program homeschooling untuk anak usia dini sebagai komunitas homeschooling. Hasil penelitian nantinya akan memberikan gambaran mengenai program homeschooling untuk anak usia dini yang dapat mengatasi atau tidak dari isu homeschooling. Maka perlu dilakukan penelitian mengenai "Implementasi Program Homeschooling untuk Anak Usia Dini di SABUMI Homeschooling Muslim Nusantara (HSMN)" besar harapan penulis untuk mendapatkan persetujuan dan dukungan dari berbagai pihak terkait.

Berdasarkan latar belakang masalah yang telah dipaparkan di atas, maka rumusan masalah dalam penelitian ini adalah:

1. Bagaimana perencanaan program homeschooling untuk Anak Usia Dini di SABUMI - Homeschooling Muslim Nusantara Bandung (HSMN)?

2. Bagaimana pelaksanaan program homeschooling untuk Anak Usia Dini di SABUMI - Homeschooling Muslim Nusantara Bandung (HSMN)?

3. Bagaimana evaluasi program homeschooling untuk Anak Usia Dini di SABUMI Homeschooling Muslim Nusantara Bandung (HSMN)?

\section{METODE}

Penelitian ini dimaksudkan untuk mengumpulkan data terkait dengan program homeschooling untuk anak usia dini di SABUMI - HSMN Bandung. Berdasarkan permasalahan yang diangkat penelitian ini menggunakan pendekatan kualitatif. Menurut Fathoni (2006, hlm. 60) mendefinisikan bahwa pendekatan kualitatif adalah sebuah penelitian yang ditujukkan untuk mendeskripsikan dan menganalsis fenomena, peristiwa, aktivitas sosial, sikap, kepercayaan, persepsi, pemikiran orang secara individual ataupun kelompok.

Penelitian berfokus pada program homeschooling untuk anak usia dini di SABUMI - HSMN Bandung. Peneliti memilih studi kasus karena penelitian ini bertujuan untuk menggali informasi dengan mempertahankan keutuhan subjek penelitian sebagai satu kesatuan yakni program homeschooling untuk anak usia dini yang terdiri dari perencanaan, pelaksanaan, serta 
evaluasi. Studi kasus adalah salah satu metode penelitian ilmu-ilmu sosial (Yin, 2008). Dalam hal ini peneliti mencari tahu perencanaan, pelaksanaan dan evaluasi dari program homeschooling untuk anak usia dini serta mencari jawaban atas permasalahan yang ada dengan memilih homeschooling.

Analisis tematik menurut Boyatzis (1998) "to capture the qualitative richness of the interview data. A scheme of thematic codes was developed to map onto the major concepts involved in the research questions." Pertanyaan tersebut memiliki arti bahwa analisis tematik merupakan suatu teknik yang digunakan dengan cara mencari tema-tema yang muncul dalam data penelitian dan tematema tersebut mengacu pada pertanyaan penelitian.

\section{HASIL PENELITIAN DAN PEMBAHASAN}

Hasil penelitian ini merupakan paparan dari berbagai hasil temuan di lapangan melalui observasi, wawancara dan dokumentasi terkait dengan program homeschoolingmeliputi perencanaan, pelaksanaan dan evaluasi program homeschooling untuk Anak Usia Dini di SABUMI -HSMN Bandung.

\section{Perencanaan Program \\ Homeschooling untuk AUD di SABUMI-Homeschooling Muslim Nusantara Bandung (HSMN).}

Perencanaan menjadi bahasan penting dalam program. Berdasarkan hasil wawancara dan observasi yang dilakukan oleh peneliti, diperoleh gambaran mengenai komunitas homeschooling SABUMI - HSMN Bandung, pembetukan kepengurusan, perencanaan program untuk anak usia dini dan beberapa temuan seperti berikut ini :

\section{a. Bentuk \\ Homeschooling \\ Admin}

Kepengurusan

mengungkapkan

kepengurusan yang terbentuk dalam komunitas homeschooling SABUMI Homeschooling Muslim Nusantara (HSMN) Bandung adalah orang tua yang berkontribusi sebagai pengajar serta komunitas sebagai fasilitator. Apabila komunitas membutuhkan orang yang ahli, akan mengundang keluarga yang mempunyai keahlian. Seperti hal yang terlihat dari petikan wawancara berikut:

Peneliti :Kalau boleh tahu, pengurus dari tim setiap program SABUMI itu dari mana teh? Apakah ada tenaga ahli atau bagaimana?

Responden:Sebenarnya pengurus dari SABUMI dalam kepengurusan itu

adalah orang tua yang berkontribusi. (a)Pengajarnya pun orangtua itu sendiri, komunitas sebagai fasilitator. Karena pengerjaannya yang dilakasanakan oleh anak dan orangtua agar adanya kerjasama serta keterikatan anak dan orangtua dalam keluarga. Jika memang diperlukan (b) tenaga ahli, kami mencarinya dari profesi dan keahlian keluarga itu teh.Subjek I (Hasil Wawancara I, 25 Agustus 2016)

Jawaban responden tersebut sesuai dengan pendapat Kembara (2007) penekanan proses pendidikan lebih pada partisipasi orang tua dalam merancang pendidikan anak-anaknya bila dalam homeschooling.

\section{b. Bentuk komunitas homeschooling}

Menurut Kembara (2007, hlm. 53) dengan bergabung dalam komunitas homeschooling, para homeschooler dapat saling berbagi dan mendukung 
dalam menjalankan program pilihannya. Selain itu, komunitas dapat menjadi perantara para homeschooler dengan pemerintah dalam mengurus masalah kesetaraan anak-anak homeschooling. Berikut petikan hasil wawancara

Peneliti :Kenapa sih teh akhirnya bergabung dan membentuk sabumi, apakah tidak ada komunitas yang sesuai dengan teteh?

Responden :Memang banyak teh komunitas homeschooling dibandung, akan tetapi visi misi yang tidak sesuai harapan. Maka dari itu kami membentuk dan menjalankan sabumi ini. Oh iya,(a) komunitas homeschooling SABUMI - HSMN Bandung itu berproses dan berkembang karena adanya Kulwap untuk orang tua (dikarenakan orangtua yang terlebihi dahulu diberikan ilmu mengenai pendidikan yang memilki landasan atau dasar) ; b)Club ; c) SHC. Perkembangan legalitas,unggul dalam segi agama (dikarenakan sabumi berlandaskan Al Quran dan Sunnah, mempunyai wadah mengenai agama, memiliki ruangan yang kondusif). Kelemahan komunitas ini adalah identitas sabumi HSMN Bandung mengenai homeschooling dianggap oleh lingkungan adalah pengajian orangtua dan kegiatan anak usia dini. Penyebabnya adalah SABUMI HSMN Bandung memberikan pendidikan terlebih dahalu oleh orangtuanya dikarenakkan yang akan mendidik anak ialah orangtua itu sendiri, mayoritas anggota sabumi HSMN Bandung ialah orang tua yang memiliki anak usia dini.Subjek I (Hasil Wawancara I, 25 Agustus 2016)

Perihal petikan wawancara dan pendapat ahli, bahwa komunitas $\begin{array}{lrr}\text { SABUMI } & \text { HSMN } & \text { Bandung } \\ \text { berproses } & \text { dan } & \text { menjalankan } \\ \text { identitasnya } & \text { sebagai } & \text { komunitas } \\ \text { homeschooling } & \text { karena } & \text { memiliki }\end{array}$ landasan dan memperkokoh ilmu orang tua terlebih dahulu.Hal ini menjawab terkait pendapat Dobson (2005) mengenai isu keraguan orang tua untuk memberikan pembelajaran yang baik pada anak. Program SABUMI-HSMN Bandung mengatasi dengan memberikan ilmu kepada orang tua akan menjadi figur bagi anak, interaksi antara keluarga menjadi intensif. Selain itu, Hanaco (2012) berpendapat bahwa manfaat yang diperoleh anak dan orangtua dari pelaksanaan homeschooling ialah memperat ikatan dalam keluarga. Poin lainnya adalah orang tua melakukan penanaman nilai dan sikap mental untuk anak-anak.

\section{c. Bentuk program online - offline}

Pada program yang dibentuk, terdapat jadwal untuk mempelajari berbagai ilmu pengetahuan yang dibutuhkan oleh anak dan anggota (member). Hal ini, sependapat dengan Dobson (2005) mengenai isu harus adanya alokasi waktu belajar seperti sekolah, karena apabila tidak adanya alokasi waktu membuat anak menjadi tidak displin. Padahal alokasi waktu ini, menepis isu bahwa peserta homeschooling tidak disiplin.

Cuplikan wawancara dibawah ini dapat diketahui mengenai alokasi waktu program SABUMI-HSMN Bandung : Peneliti :Apakah dari program SABUMI yang disebutkan teteh, memiliki jadwal atau kesepakatan dengan member (anggota) teh?

Responden :Kalau itu sudah ada jadwal perbulannya yang dibagi per pekan untuk tampil program online atau offline dibentuknya oleh tim 
pengurus dari setiap program dan di laporkan oleh koordinator wilayah (korwil). Nanti bisa dilihat jadwalnya ya teh. Subjek I (Hasil Wawancara I, 25 Agustus 2016)

Hal ini berkaitan dengan pendapat ahli mengenai programprogram yang dibuat oleh SABUMI HSMN Bandung yaitu Dobson (2005, hlm. 272)

"Program-program bersekolah rumah menawarkan bentuk lain dari kebebasan pendidikan, pembelajaran yang bebas dari keharusan dan peraturan pemerintah."

Program - program yang terdiri dari online dan offline di SABUMI HSMN Bandung, merupakan keunggulan yang terlihat oleh peneliti, karena bila hanya ada salah satu yang dikerjakan, maka tidak akan dapat mengembangkan perkembangan anak. Program tersebut saling berkaitan karena menjadi solusi untuk keluarga yang memilih homeschooling. Diskusi antar keluarga membuat orang tua mendapatkan ide dari keterangan yang dipublikasikan oleh orang tua. Hal ini, tidak terlupakan oleh SABUMI - HSMN yang mempunyai format dokumentasi pembelajaran dalam program yang dipakai. Berikut petikan dan dokumentasi yang peneliti dapat :

Peneliti :Apakah formatnya yang sering ditampilkan dalam program online ya teh, dan bagaimana dengan program offline?

Responden :Iya benar sekali teh, seperti ini formatdokumentasi pembelajaran dalam program online terdiri dari grup hsmn; nama; tema ; tujuan pembelajaran ; usia anak; alat dan bahan; cara membuat \& proses; foto pembelajaran (lampiran); kalau offline ada worksheet dan perkembangan kemampuan akan di evaluasi oleh orang tua masing-masing Subjek I (Hasil Wawancara I, 25 Agustus 2016)

\section{d. Perkembangan komunitas homeschooling di SABUMI - HSMN Bandung}

Setiap komunitas mempunyai ciri khas tersendiri, begitu pun dengan komunitas homeschooling SABUMI HSMN. Pada awal perjalanan, komunitas ini memiliki anggapan dari lingkungan sekitar sebagai pengajian orang tua dan kegiatan anak usia dini. Berikut petikan wawancara responden mengenai perkembangan komunitas yang diperoleh peneliti:

Responden :identitas sabumi HSMN Bandung mengenai homeschooling dianggap oleh lingkungan adalah pengajian orangtua dan kegiatan anak usia dini. Penyebabnya adalah sabumi HSMN Bandung memberikan pendidikan terlebih dahalu oleh orangtuanya dikarenakkan yang akan mendidik anak ialah orangtua itu sendiri, mayoritas anggota sabumi HSMN Bandung ialah orang tua yang memiliki anak usia dini. Subjek I (Hasil Wawancara I, 25 Agustus 2016)

Petikan tersebut, menjelaskan bahwa orang tua adalah orang yang utama dan pertama dalam pendidikan untuk anak. Oleh karena itu SABUMI HSMN Bandung mendidik orang tua terlebih dahulu dibandingkan anak. Hal ini, sesuai dengan pendapat dari Dobson (2005) orang tua yang mengenal anak paling baik dibandingkan dengan siapapun serta orang tua adalah orang terbaik untuk mendidik mereka. 
Orangtua merupkan bagian utama anak belajar dan bersosialisasi.

Komunitas homeschooling

SABUMI-Homeschooling Muslim Nusantara(HSMN) Bandung, melakukan perjalanannya dengan mengambil berbagai pelajaran dan pengalaman lalu memadukan keduanya (antara pengalaman dan pelajaran tersebut). Proses inilah yang ternyata mengklarifikasi mengenai isu homeschooling gagap teknologi, hal yang salah karena justru homeschooling memiliki peluang besar untuk mengakses internet. Terlihat dari hasil wawancara diatas bahwa SABUMI HSMN Bandung yang menggunakan media online yaitu whatsApp dan facebook. Berbagai solusi dan perbaikan dalam program dibuat, untuk perkembangan berbagai elemen seperti anak, orang tua, keluarga dan lingkungan sekitar.

\section{e. Visi misi dan prinsip sesuai dengan keluarga}

Sebuah keluarga memiliki visi dan misi untuk membentuk keluarga yang diharapkan, karena itulah sebuah komunitas memiliki visi dan misi pula. Hal ini yang membuat orang tua memilih komunitas homeschooling yang sesuai dengan harapan keluarga, seperti halnya petikan responden yang peneliti dapat:

Responden :Keduanya dong teh, karena(a) visi misi yang sesuai dengan keluarga, mencari prinsip yang sama sangat sulit yang sesuai dengan Al Quran dan Sunnah dan sangat terbantu. Selain itu, program yang dibuat oleh HSMN Bandung membuat orang tua dapat (b)menambah mengembangkan ide dalam mendidik anak dari media serta menuntaskan kesulitan. Subjek I (Hasil Wawancara I, 25 Agustus 2016)
Hal ini sesuai dengan pendapat Dobson (2005) yaitu motivasi yang menjadi komitmen kuat keluarga memilih homeschooling, pengeluaran biaya, pendekatan yang dilakukan sesuai dengan cara belajar dan pribadi manusia yang unik, penilaian anak yang sesuai dalam program homeschooling untuk anak usia dini di SABUMI - HSMN Bandung, teknologi yang dapat diperoleh dengan gratis hingga berbayar, tempat belajar dimana saja dan kapan saja, keterlibatan orangtua serta bantuan dari luar yang bermanfaat menjembatani ketertinggalan akademis, memberi kesempatan kepada anak untuk mendalami ketertarikan mereka, memberi kesempatan kepada anak bergaul yang lebih luas, membuka kesempatan untuk melakukan kegiatan sosial, menambah kesempatan untuk melakukan kegiatan fisik.

\section{f. Bentuk perencanaan program online dan offline.}

Penyusunan rencana yang dibuat oleh SABUMI - HSMN Bandung, tercerminkan pada petikan wawancara berikut,

Peneliti :Apakah program online dan offline homeschooling SABUMI memiliki perencanaan seperti halnya TK pada usia AUD?

Responden :Tentu saja ka, perencanaan sudah dilakukan, misalnya tim sabumi menyesuaikan jadwal playdate per wilayah, membentuk beberapa klub online supaya kegiatan ananda terakomodir walaupun tidak selalu berupa pertemuan tatap muka(offline), selain itu seperti halnya TK ada evaluasinya, sejauh ini memang member sabumi banyak, dan heterogen dari segi pendidikan, ekonomi, minat dll. ini yang membuat kadang pertemuan offline 
sulit terlaksana secara merata di seluruh wilayah. hanya wilayah-wilayah tertentu saja yg rutin playdate offline (bandung timur contohnya). Sebelumnya, diawali dengan dua club dan playdate sabumi, dibulan oktober terdapat beberapa kegiatan yang dibuat seperti cookingclass dan arabic dilanjutkan dengan program offline yang dibutuhkan oleh member/anggtaSubjek II (Hasil Wawancara II, 8 September 2016)

Pada petikan wawancara diatas subjek II tidak menjelaskan secara rincimengenai perencanaan program online-offline, tetapi menjelaskan mengenai program-program SABUMI HSMN Bandung yang memiliki kelebihan dan kelemahan beberapa program serta evaluasi.Faktor tersebut menyebabkan bentuk perencanaan program online-offline disesuaikan dengan perkembangan dan kebutuhan anak.

\section{g. Orientasi tujuan ke akhirat}

Peneliti :Apakah mengetahui perbedaan PAUD dengan homeschooling selaku orang tua?

Responden :Ya mengetahui perbedaan antara PAUD dan homeschooling, karena ini adalah pilihan dengan alasan memilih homeschooling dibandingkan PAUD atau TK karena sudah tidak ada kepercayaan dengan pendidikan umum. (a) Orientasi yang bukan hanya untuk pekerjaan tapi akhirat. Kecewa dengan banyak hal ponografi, bullying, keadaan sosial yang tidak baik (berdasarkan berita). Berawal dari salah satu yang memilih dengan memberikan data perihal pendidikan yang terjadi dinegara ini akhirnya memilih menetapkan untuk homeschooling.
Karena homeschooling, budgetnya tidak banyak. Aplikasi yang dipakai tidak sesuai dengan orang yang berilmu. Belajar hanya sekedar tahu tidak di aplikasikan. Mencontek, bayar kunci jawaban dsb. Pintar tapi tak berakhlak. Selain itu, mencari keluarga dalam komunitas yang visi misinya sama sangat jarang, mencari ridhoNya Allah (akhirat), alhamdulillah SABUMI-HSMN Bandung adalah komunitas homeschooling yang sesuai dengan keluarga. Subjek III (Hasil Wawancara III, 12 September 2016 ; 21 September 2016)

Berdasarkan petikan wawancara diatas dan penelusuran berita yang dilakukan oleh peneliti,bahwa SABUMI - Homeschooling Muslim Nusantara (HSMN) Bandung membentuk komunitas homeschooling yang berlandaskan sesuai dengan agama,hal ini sependapat dengan petikan wawancara mengenai pendidikan sepanjang hayat adalah pendidikan yang dimulai berkelanjutan yang tidak dibatasi oleh dimensi ruang, individu, waktu dan berbagai kepentingan, akan berpengaruh baik untuk setiap orang mengetahui hak dan kewajiban sebagai individu, kelompok dan masyarakat serta sebagai makhluk Tuhan (Sunarti,2013). SABUMI - Homeschooling Muslim Nusantara (HSMN) Bandung merupakan salah satu solusi orang tua untuk mengikuti komunitashomeschooling karena proses program yang diberikan sesuai dengan visi, misi dan tujuan dalam keluarga.

2. Pelaksanaan Program Homeschooling untuk AUD di SABUMI-Homeschooling Muslim Nusantara Bandung (HSMN).

Pelaksanaan program homeschooling untuk anak usia dini di 
$\begin{array}{lrr}\text { SABUMI } & \text { Homeschooling } & \text { Muslim } \\ \text { Nusantara } & \text { (HSMN) } & \text { Bandung } \\ \text { mengklarifikasi isu dengan adanya }\end{array}$ tanggung jawab komunitas, anggota member komunitas, kebutuhan member, pelaksanaan program homeschooling untuk anak terdiri dari program onlineoffline, mendapatkan pembelajaran bagi orang tua, sarana dan prasarana disesuaikan dengan kebutuhan keluarga.

Hal ini menjawab isu terkait homeschooling yang sependapat dengan Kembara (2007, hlm. 76) yaitu kurang bersosialisasi anak yang homeschooling, keraguan orang tua memberikan pendidikan untuk anak, homeschooling hanyauntuk keluarga kaya, homeschooling gagap teknologi, peserta homeschooling tidak disiplin.

\section{a. Tanggung kepengurusan komunitas}

Pelaksanaan tidak akan berjalan dengan baik apabila tidak yang bertanggung jawab. Seperti halnya sebuah petikan wawancara yang menjelaskan mengenai tanggung jawab dari bagian komunitas SABUMI - HSMN Bandung

Peneliti :Kenapa harus dilaporkan kepada korwil teh?

Responden :Karena tugas korwil antara lain mengawasi dan mengawal jobdesk admin, memastikan seluruh pengurus bisa mjalankan tugas dg baik,memastikan grup bisa memfasilitasi kegiatan hser di wilayahnya (supporting grup).Subjek I (Hasil Wawancara I, 25 Agustus 2016)

Admin tidak menjelaskan secara rinci dalam penggalan petikan wawancara, akan tetapi bagian tanggung jawab yang diamanahi merupakan peran yang besar dalam keberjalanan pelaksanan program homeschooling untuk anak usia dini.Sedangkan berdasarkan petikan wawancara di bawah dengan koordinator wilayah, dapat diketahui bahwa tanggung jawab dalam kepengurusan komunitas terdapat pembagian penanggung jawab dipahami oleh responden, serta dengan pemahaman perencanaan program online-offline homeschooling untuk anak usia dini akan tetapi tidak dijelaskan secara rinci.

Peneliti :Oh iya teh, ini jadwal program homeschooling sabumi dibulan agustus (menunjuk poster) bagaimana teh persiapannya?

Responden :Kita mulai dari perannya ya ka,yang bertanggung jawab ialah korwil dan koordinator, yang membuatilah tim itu sendiri ialah orang tau yang memegang amanah sebagai tim. Lalu penjadwalannya dengan disesuaikan dengan kesepakatan, dibuat rancangan dalam jangka 6 bulan kedepan. Serta terdapat lampiran contoh jadwal yang dilaksanakan oleh setiap tim yang digabung menjadi satu. Subjek II (Hasil Wawancara II, 8 September 2016)

b. Anggota (member) Komunitas Homeschooling

Dobson (2005) mengatakan bahwa komunitas bila sepuluh atau keluarga yang bersekolah rumah, akan muncul kelas-kelas kelompok atau lebih yang terdata dan untuk keluargakeluarga yang memanfaatkannya. Hal ini diperkuat dengan petikan wawancara yang peneliti dapat, bahwa SABUMI HSMN Bandung merupakan sebuah komunitas, berikut petikan wawancara :

Peneliti :Kalau boleh tahu, berapa jumlah member/anggota dari SABUMI - HSMN Bandung teh?

Responden :Jumlah keluarga yang tedaftar di SABUMI kira-kira jumlahnya 225 orang terdiri dari grup WA sabumi $l=108$ orang ; 
sabumi2 = 36orang ; sabumi $3=$ 81orang.Subjek I (Hasil Wawancara I, 25 Agustus 2016)

Dari petikan wawancara diatas terlihat bahwa SABUMI - HSMN Bandung menggunakan media sosial yaitu whatsApp, Menurut Dobson (2005) menggunakan internet memenuhi dengan banyak informasi potensial dan bahaya potensial. Peneliti mendapati info mengenai perkiraan keluarga yang mempunyai anak usia dini dalam komunitas homeschooling SABUMI HSMN Bandung, berikut petikan wawancaranya :

Peneliti :Wah banyak sekali ya teh, kalau boleh tahu usia anak yang menjadi bagian dari SABUMI HSMN Bandung berapa dan persentase keluarga yang memiliki anak usia dini?

Responden :Kira-kira 85 persen disetiap grup memiliki anak usia dini, akan tetapi data dalam google document belum lengkap karena belum semua keluarga mengisi. Kalau anak-anak member rentang usianya dari 0 tahun sampai belasan. Subjek I (Hasil Wawancara I, 25 Agustus 2016)

\section{c. Kebutuhan member}

Peneliti :Kalau menurut teteh, homeschooling itu apa memang ada untuk anak usia dini?

Responden :Pada dasarnya homeschooling untuk usia sekolah dari SD hingga SMA, akan tetapi pada sabumi, mayoritas yang bergabung adalah orang tua yang mempunyai anak usia dini, maka dari itulah dibuat program yang memenuhi kebutuhan member. Diketahui bahwa dalam sabumi diawali dengan pemberian ilmu terhadap orang tua, karena role modelnya bila homeschooling adalah orang tua itu sendiri. Subjek III (Hasil Wawancara III, 12 September 2016 ; 21 September 2016)

Kebutuhan member yang diberikan oleh SABUMI - HSMN Bandung terlihat dari petikan wawancara, mengutamakan orang tua. Hal ini sesuai dengan pendapat Sunarti (2013, hlm. 282) Keluarga sebagai wadah pendidikan pertama dan utama memiliki peranan yang sangat penting dalam mewujudkan dan mempersiapkan generasi penerus ke arah yang lebih baik. Sependapat dengan Hanaco (2012, hlm 77) orangtua bertanggung jawab penuh terhadap pendidikan buah hatinya dan memegang kendali seutuhnya. Orangtualah yang menjadi penentu sukses tidaknya homeschooling.

\section{d. Pelaksanaan program online dan offline}

Peneliti :Lalu, bagaimana pelaksanaan program homeschooling untuk AUD di SABUMI - HSMN Bandung?

Responden :Pelaksanaan berjalan dengan baik untuk beberapa program. Dengan beberapa perubahan seperti jam tayang kelas, mempengaruhi antusias lebih oleh member. Untuk kelas online setiap hari selasa dan jumat setiap dua pekan bergantian. Fieldtrip setiap sebulan sekali. Thifan di akhir minggu pekan dengan akhir smester ada tes. Cunami, Playdate disesuaikan perwilayah bandung dan koordinasi anggota dengan pengurus. Kakak dapat menyimak grup dalam program online dan ikut serta dalam program offline. Lalu setiap kegiatan akan di pubikasikan di grup facebook.

Rangkaian program-program yang dibentuk SABUMI - HSMN 
Bandung, memanfaatkan sarana publik selain di rumah, sesuai dengan pendapat Adilistiono (2010, hlm. 2) proses belajar yang berpusat di rumah, tetapi orang tua dapat menggunakan sarana apa saja dan dimana saja untuk melakukan pendidikan, pengayakan dan memanfaatkan infrastruktur serta sarana masyarakat yang ada. Sepertiyang digunakan untuk pembelajaran dapat menggunakan sarana gratis atau berbayar, seperti fasilitas pendidikan (perpustakaan, museum, lembaga penelitian), fasilitas umum (taman, statiun, terminal, jalan raya), fasilitas sosial (panti, rumah sakit), maupun fasilitas bisnis (restoran, pabrik, perkebunan, mall).

\section{e. Pembelajaran untuk orang tua}

Program yang dibuat oleh HSMN Bandung membuat orang tua dapat menambah mengembangkan ide dalam mendidik anak dari media serta kesulitan sesuai dengan cuplikan wawancara kepada pengurus.

Peneliti :Bagaimana ayah dan bunda bisa bergabung dalam komunitas homeschooling sabumihsmn bandung?

Responden :Awalnya mencari di media sosial mengenai homeschooling, lalu mengikuti kopdar dengan (a) visi misi yang sesuai dengan keluarga, mencari prinsip yang sama sangat sulit, karena itu sangat terbantu. Selain itu,(b) program yang dibuat oleh HSMN Bandung membuat orang tua dapat menambah mengembangkan ide dalam mendidik anak dari media serta kesulitan. Subjek III (Hasil Wawancara III, 12 September 2016 ; 21 September 2016)

Petikan di atas, responden membahas mengenai manfaat yang didapat orangtua, hal ini sesuai dengan pendapat Hanaco (2012, hlm. 13) syarat utama orangtua memilih homeschooling, seperti 1) komitmen karena orangtua adalah pemegang kendalinya, 2) mencintai anak, 3) disiplin karena saat memilih homeschooling berarti ada peraturan yang harus dipatuhi, 4) mau belajar, 5) kreatif dengan pengertian dapat menciptakan suasana belajar yang tidak kaku, 6) orientasi kedepan, 7) tidak mudah putus asa, 8) sabar, 9) kerja keras. Pastinya, karena orangtua pun belajar dan menjadi kreatif, serta dapat berbagi pada masyarakat dengan cara mempublikasi aktivitasnya dalam program online atau offline ke blog, grup facebook.

f. Sarana dan prasarana yang disesuaikan dengan kebutuhan keluarga.

Sarana dan prasana saat online di sesuaikan dengan kelurga masingmasing tidak memberatkan harus mahal. Untuk offline pun ada biaya yang dtanggung itu pun pilihan dapat mengikuti atau pun tidak, mejadi kebebasan dalam memilih setiap keluarga.

Peneliti :Dari beberapa program yang ada, bagaimana sarana dan prasana yang dipakai anak untuk program homeschooling untuk AUD?

Responden :Sarana dan prasana saat online di sesuaikan dengan kelurga masing-masing tidak memberatkan harus mahal. Untuk offline pun ada biaya yang dtanggung itu pun pilihan dapat mengikuti atau pun tidak, mejadi kebebasan dalam memilih setiap keluarga. Subjek III (Hasil Wawancara III, 12 September 2016 ; 21 September 2016)

3. Evaluasi Program Homeschooling untuk AUD di SABUMI- 


\section{Homeschooling Muslim Nusantara Bandung (HSMN). \\ a. Isu \\ homeschooling dengan \\ program SABUMI - HSMN \\ Bandung}

Wawancara yang dilakukan

dengan subjek III, peneliti mendapatkan info bahwa isu homeschooling yang beredar salah.

Peneliti :Teh, banyak sekali isu mengenai hs, bagaimana mengatasi isu permasalahan di homeschooling dengan program yang dibuat atau ada kegiatan lainnya?

Responden :Isunya seperti sosialisasi itu salah karena dalam homeschooling anak belajar dari usia sebaya hingga lebih dewasa atau muda (multi level). Isu lainnya seperti biaya yang terlampau mahal itu pun juga salah karena seтиa aktivitas yang dilakukan sesuai dengan kemauan anak, perkembangan anak yang dipilah oleh orang tua yang sesuai dengan aktivitasnya, serta barang atau bahan yang diperlukan yang ada di rumah, tak membuat sulit member/anggota. Subjek III (Hasil Wawancara III, 12 September 2016 ; 21 September 2016)

Hal yang menarik ternyata isu homeschooling oleh Dobson (2005, hlm. 91) mengenai kurang sosialisasi anak terhadap lingkungan tidak benar. Sebab dari jawaban responden anak dapat bersosialisasi secara multi level. Sependapat dengan pendapat dari Grifftth (2008) yaitu pendidikan tanpa sekolah merupakan sebuah proses yang cenderung menghasilkan individu dengan karakteristik-karakteristik tertentu seperti belajar sama alaminya dengan bernafas, anak menyadari bahwa manusia berbeda dan mempelajari hal yang berbeda-beda, maka cenderung memiliki kepintarannya masing-masing, anak lebih tertarik dan toleransi terhadap keanekaragaman manusia dibandingkan dengan pergi ke sekolah yang cenderung tidak terpusat oleh ideide dan kegiatan teman sebaya, anakanak yang homeschooling cenderung memiliki perasaan yang baik akan dirinya sendiri, mempunyai rasa percaya diri untuk belajar, untuk memikirkan sendiri mengenai berbagai hal, berani meminta tolong kepada sekitar bila mengalami kesulitan, mereka pemikir yang kritis yang mencari kosistensi dan perasaan dalam hal-hal yang mereka dengar dan baca. Isu mengenai tidak dapat bersosialisasi, itu adalah salah ternyata saat observasi anak dapat berinteraksi dengan berbagai usia ini disebut dengan multiple intelegent, anak mencintai lingkungannya dan Negara dengan tercerminnya perilaku seharihari.

\section{b. Ilmu mendidik anak.}

Admin menyadari bahwa keluarga homeschooling yang bergabung dalam SABUMI - HSMN Bandung mendapat berbagai manfaat dan dapat mengatasi permasalahan yang dihadapi, seperti yang tercermin dari ungkapan petikan wawancara berikut,

Responden :...menambah

mengembangkan ide dalam mendidik anak dari media serta menuntaskan kesulitan. Subjek I (Hasil Wawancara I, 25 Agustus 2016)

Hal ini sesuai dengan pendapat Adilistiono (2010, hlm. 3) mengenai manfaat homeschooling yaitu salah satunya memberikan kemudahan belajar karena fleksibel, dikarenakan homeschooling mempunyai kelenturan atau fleksibilitas yang berbeda dengan sekolah formal yang tidak boleh kaku dan terlalu berstruktur. 


\section{c. Perkembangan program komunitas}

Menurut Kembara (2007) adalah program homechooling bagi orang tua yang memantapkan dengan memilih homeschooling bukan hal yang sederhana. Maka dari itu orang tua mengikuti komunitas dan mempelajari dari studi buku, internet, berbagi pengalaman dengan siapa saja serta kepada komunitas. Hal ini sesuai dengan petikan wawancara antara peneliti dengan admin. Berikut petikan wawancara tersebut:

Peneliti :Wah, memanfaatkan lingkungan dalam SABUMI ya teh, lalu apakah program disesuaikan dengan perkembangan AUD?

Responden :Iya benar sekali teh, sebenarnya diawal kami membuat program untuk ortu, anak karena sabumi-hsmn bandung menitik beratkan dengan sesuai kebutuhan member. Yang nantinya ada evaluasi yang akan dipublikasi. Serta mengundang seseorang/ keluarga yang ahli dengan bidangnya yang sesuai dengan visi misi sabumi. Subjek I (Hasil Wawancara I, 25 Agustus 2016)

\section{d. Silent reader}

Peneliti :Apakah ada kendala teh selama ini dari program yang dibentuk oleh SABUMI?

Responden :Pasti ada teh, salah satunya seperti kepengurusan. Tidak banyak orang tua yang mau dan bisa menjadi tim, (a)adanya silent reader. Maka dari itu, saat ini kami akan (b)mengeksekusi kepengurusan dan member (anggota) sabumi serta dilihat dengan kontribusi yang rutin. Subjek I (Hasil Wawancara I, 25 Agustus 2016)

Petikan diatas menjelaskan bahwa orang tua selaku bagian komunitas tidak melakukan keikutsertaan. Karena sesuai dengan pendapat Dobson (2005) jadilah relawan dalam komunitas bersama anak anda, yang diartikan yaitu dengan bersumbangsih pada komunitas dan berkenalan dengan orang dewasa yang akan dia anggap sebagai teman atau mungkin calon mentornya. Maka dari itulah, tindakan admin melakukan eksekusi terhadap keluarga yang silent reader dalam grup whatsApp.

\section{e. Sosialisasi anak}

Ditengah permasalahan yang dihadapi oleh keluarga yang memilih homeschooling, program homeschooling untuk anak usia dini di SABUMI HSMN Bandung tidak memilikipermasalahan tersebut. Bahkan hadir solusi yaitu membuat program fieldtrip yang dapatberpengaruh pada permasalahan sosial yang dihadipi anak. Petikan wawancara dibawah ini akan menjelaskan mengenai sosialisai anak,yaitu sebagai berikut:

Responden :sejauh ini responnya bagus tapi saya melihat yang lebih mendapat perhatian dan apresiasi itu adalah kegiatan field trip. Ini mungkin karena orang tua -orang tua anak HS AUD ini butuh kegiatan yang aktivitasnya diluar rumah. Agar anak-anaknya bersosialisasi dengan teman sebaya dan supaya lebih medapat pengalaman langsung. Subjek II (Hasil Wawancara II, 8 September 2016)

\section{f. Kendala internal dan ekternal dari program homeschooling}

Berbagai kebutuhan anggota/member yang dipenuhi oleh admin, korwil bahkan pengurus;serta dengan adanya beberapa program homeschooling yang terdiri dari online dan offline, tidak selamanya 
dapat berjalan dengan konsisten. Adapun kendala yang dihadapi dapat dilihat pada petikan wawancara berikut:

Peneliti :Apakah ada kendala teh dan bagaimana peran orang tua dalam program homeschooling di sabumi - hsmn bandung?

Responden:Kalau kendala ada dari internal dan ekternal ka. Kalau internal yaitu contohnya ya untuk program online seperti kegiatan bahasa arab sebelunya materi yang sulit, adanya evaluasi dan permintaan dapat diperbaiki dan menjadi menyenangkn, untuk program lainnya tidak ada masalah. Bila untuk program offline terdapat kendala seperti kegiatan playdate yang tidak konsisten untuk melaksanakan karena domisili yang jauh dan perbedaan latar bekang keluarga. Selain itu, ada fieldtrip yang berkuota tidak bisa semua ikut serta karena koordinator dalam tim yang kurang (SDM) .Kalau perannya dengan kontribusi orangtua selama ini antusias dengan programprogram yang di buat oleh tim dalam online maupun offline. Sepertinya halnya offline yang selalu memenuhi kuota dan waiting list . Subjek II (Hasil Wawancara II, 8 September 2016)

Berdasarkan petikan wawancara diatas, peneliti memperoleh gambaran bahwa komunitas ibarat sebuah keluarga, apabila salah satunya tidak dapat berkontribusi dengan baik, maka akan hadir kendala yang membuat terbengkalai salah satu program. Perlu adanya, perbaikan dan solusi-solusi yang dapat membangun kondisi internal maupun eksternal dari suatu komunitas. Seperti tercermin dari petikan wawancara berikut

Peneliti :Kalau begitu, apakah ada kendala dari dua program tersebut teh?

Responden :Kendala fieldtrip mungkin dari sumber daya manusianya kurang ya, kurang penanggung jawabnya, sehingga kurang mengakomodir seluruh member yg berminat ikut fieldtrip. Kalo kendala playdate ya itu tadi, domisili member yg terpencarpencar walaupun masih satu wilayah dan juga kesibukan atau kepentingan member yang berbeda - beda, apalagi yaa kendalanya. Subjek II (Hasil Wawancara II, 8 September 2016)

Petikan wawancara tersebut merupakan contoh dari kendala yang dihadapi oleh sebuah komunitas homeschooling, dimana mayoritas keluarga mempunyai anak usia dini, serta respon orang tua yang kurang untuk menjadi pengurus. Hal ini mengingatkan arti homeschooling komunitas menurut Adilistiono (2010, hlm. 3) yaitu gabungan beberapa homeschooling yang menyusun dan menentukan silabus, bahan ajar, kegiatan pokok (olahraga, musik/seni, dan bahasa), sarana/prasarana dan jadwal pembelajaran. Komitmen penyelenggaran pembelajaran antara orangtua dan komunitasnya kurang lebih 50:50. Pada kenyataannya komitmen yang diberikan orangtua dalam komunitas SABUMI - HSMN Bandung belum sesuai dengan penerapannya. Bila komitmen seluruh orangtua sesuai, program-program yang dibentuk akan bersinergi dengan lainnya.

SIMPULAN 
Berdasarkan hasil penelitian dan analisis pembahasan pada bab sebelumnya, berikut simpulan yang diperoleh oleh peneliti:

1. Dari segi perencanaan program homenschooling untuk anak usia dini di SABUMI-Homeschooling Nusantara (HSMN) Bandung sudah cukup baik. Hal ini terlihat dari perencanaan dibuat program kerja untuk enam bulan kedepan dengan kebebasan program yang menjadi keunggulan homeschooling yang melibatkan pengurus setiap tim program online-offline, koordinaor wilayah dan admin. Bentuk kepengurusan komunitas yang mengelola selaku orang tua terdaftar sebagai anggota homeschooling. Perencanaan program homeschooling di komunitas ini, memberikan informasi terkait perkembangan komunitas homeschooling SABUMI-HSMN Bandung dengan visi misi yang berbasis Al Quran dan sunnah sesuai dengan pilihan keluarga dan orientasi tujuan akhirat. Bentuk program homeschooling untuk anak usia dini menggunakan media sosial dan berkumpul atau bertamasya yang disebut dengan program online dan program offline, mempunyai jadwal setiap pekannya dalam satu bulan.

2. Pelaksanaan program homeschooling untuk anak usia dini di SABUMI-Homeschooling Muslim Nusantara (HSMN) Bandung menjadi tanggung jawab komunitas. Pelaksanaan program homeschooling untuk anak usia dini disesuaikan dengan kebutuhan member.
Pelaksanaan program untuk anak usia dini terdiri dari dua program yaitu online menggunakan WhatsApp dan offline sebagai pelengkap menjadi program yang utuh bagi anak. Pada pelaksanaan program ini, memberikan solusi orang tua yang memilih homeschooling untuk anak terkait isu homeschooling yang beredar serta memberikan pembelajaran bagi orang tua menggunakan sarana dan prasarana yang disesuaikan dengan kebutuhan keluarga. Terlihat pada proses observasi melalui whatsApp anak-anak melaksanakan program sesuai kreatifitas, sarana prasarana yang ada, bahan yang dibutuhkan dengan jadwal yang telah ditentukan.

3. Evaluasi program untuk anak usia dini di SABUMIHomeschooling Muslim Nusantara (HSMN) Bandung dapat mengatasi isu permasalahan homeschooling yang beredar, perihal mengenai kurang sosialisasi anak terhadap lingkungan, keraguan orang tua memberikan pendidikan untuk anak, homeschooling hanya untuk keluarga kaya, homeschooling gagap teknologi, harus adanya alokasi waktu belajar seperti sekolah, peserta homeschooling tidak disiplin. Perihal isu tersebut, diatasi dengan perencanaan dan pelaksanaan dari program homeschooling yang dibentuk dengan dua program dan menjadi kelebihan karena homeschooling meempunyai kebebasan membuat program serta 
dipengaruhi dengan kebutuhan anggota (member). Sedangkan evaluasi dari pelaksanaan program homeschooling untuk anak yang terdiri dari online dan offline belum terlaksana dengan baik dikarenakan belum adanya poin terkait aspek perkembangan anak untuk mengetahui sejauh mana anak berkembang. Dengan adanya program homeschooling ilmu mendidik anak, perkembangan program komunitas, silent reader, kendala internal dan eksternal dari program homeschooling

\section{DAFTAR PUSTAKA}

Adilistiono. (2010). Homeschooling Sebagai Alternatif Pendidikan. Ragam Jurnal Pengembangan Humaniora, Vol 10 No 1 , Politeknik Negeri Semarang.April.

Boyatzis, E Richard. (1998). Transforming Qualitatitive Information: Thematic Analysis and Code Development. Universitas Michigan: Sage Publications.

Dobson, Linda. (2005). Tamasya Belajar (Panduan Merancang Program Bersekolah Dirumah Untuk Anak Usia Dini). Bandung : MLC.

Fathoni, Abdurrahmat. (2006).

Metodologi Penelitian \& Teknik Penyusunan Skripsi. Jakarta: PT Rineka Cipta.

Griffith, Mary. (2008) Sekolah Dirumah (Memanfaatkan Seluruh Dunia Sebagai Ruang Kelas). Bandung : Nuansa.

Hanaco, Indah . (2012). I Love Homescooling (Segala Sesuatu Yang Harus Diketahui Tentang
Homeschooling). Jakarta : PT Elex Media Komputindo.

Kembara, Maulia D. (2007). Panduan Lengkap Homeschooling. Bandung : Progressio n.

Kho, Loy. (2007). Homeschooling Untuk Anak, Mengapa Tidak?. Yogyakarta: Kanisius.

Sujiono, Yuliani Nurani. (2009). Konsep Dasar Pendidikan Anak Usia Dini. Jakarta: Indeks.

Sunarti. (2013). Asuhan Kehamilan. Jakarta: In media.

Yin, Robert. K. (2008). Case Study

Research: Design and Methods (Applied Social Research Methods). Illinois : Sage Publication, Inc. 